\title{
CORRIDOS, TEQUILA (AND OTHERS), AND MEXICAN/CHICANO MASCULINITY
}

\author{
Amaia Ibarraran-Bigalondo \\ Euskal Herriko Unibertsitatea/Universidad del País Vasco*
}

\begin{abstract}
The Mexican corrido is one of the most popular cultural manifestations both in the United States and Mexico. From its origins in the mid-nineteenth century, the corrido has dealt with "people's stuff," such as war, love, honor, immigration and/or belonging to a land, among other everyday life issues. The corrido is, in short, a symbol of identity and belonging, and can be considered a marker of the Mexican identity on both sides of the border. In this sense, it is to be expected that the corrido, as an expression of "people's stuff," voices the relevance of a "national" symbol. In the same way, tequila is regarded, at least internationally, as directly related to "lo mexicano/chicano," and in many cases also to Mexican/Chicano masculinity. Starting from this premise, the aim of this article is to observe the presence of tequila and its significance as a symbol of "lo mexicano/chicano" in the work of Los Tigres del Norte, one of the most prominent corrido bands, both locally and internationally.
\end{abstract}

Keywords: Corridos, Tequila, Masculinity, Los Tigres del Norte.

\section{CORRIDOS, TEQUILA (Y OTROS), \\ Y MASCULINIDAD MEXICANA/CHICANA}

\section{RESUMEN}

El corrido mexicano es una de las manifestaciones culturales más populares tanto en los Estados Unidos como en México. Desde sus orígenes a mediados del siglo XIX, el corrido se ha ocupado de "cosas de la gente", como la guerra, el amor, el honor, la inmigración y/o la pertenencia a una tierra, entre otros temas de la vida cotidiana. El corrido es, en resumen, un símbolo de identidad y puede considerarse una marca de la identidad mexicana en ambos lados de la frontera. Del mismo modo, el tequila se relaciona, al menos internacionalmente, con "lo mexicano/chicano". Y en muchos casos, con la masculinidad mexicana/chicana. En este sentido, es de esperar que el corrido, como expresión de "cosas de la gente", exprese la relevancia de este símbolo "nacional". A partir de esta premisa, el objetivo de este ensayo es observar la presencia del tequila y su significado como símbolo de "lo mexicano/chicano" en el trabajo de Los Tigres del Norte, una de las bandas de corrido más prominentes tanto a nivel local como internacional.

Palabras clave: Corridos, tequila, masculinidad, Los Tigres del Norte.

DOI: https://doi.org/10.25145/j.recaesin.2020.81.03 
Alcohol is the "stuff of everyday life" (Wilson 12). Starting from these two simple statements, this article observes the way corridos represent the "everyday-stuff" status of alcohol, and, in particular, of tequila as a vehicle for the construction of a Mexican/Chicano masculine identity. For this purpose, the article looks into the signification and relevance of the portrayal of (tequila) drinking behaviors for the construction of a Mexican/Chicano male identity in the corridos of Los Tigres del Norte, likely the most representative and internationally acclaimed corrido band.

\section{A SHORT HISTORICAL REVIEW}

Alcohol consumption is an ancient personal and social practice. In the particular case of tequila, considered by many to be the Mexican national drink, the first records that account for its use and consumption date back to pre-Columbian times. In her 2014 comprehensive study on the origins, uses and meanings of tequila, Marie Sarita Gaytán purports that:

Pulque, mezcal, and tequila derive from the agave, also known as the maguey, or the century plant. Indigenous legends recorded by Mesoamerican and Spanish clergy relate stories about the origin of agave, pulque, and their interconnections. For example, the fifteenth century pre-Hispanic Nuttal codex described seventeen types of agave used by the Mixteca. Spanish chronicler Fray Bernardino de Sahagún noted that the Olmeca credited male gods, including Tepuztecatl, Quatlapanqui, Tliloa, and Papaztactzocaca, with inventing pulque. (18)

These words, which expose the ancient origins of the drink, highlight two other issues that are relevant for the development of this article. The first is that the existence and consumption of all drinks deriving from the agave plant were recorded and transmitted through diverse forms of popular culture; the second is that it was, as observed in the said records, both by the indigenous populations and the Spanish ones, directly related to "lo masculino," and, in this particular case, to male Gods.

Gaytán highlights the relevance of pulque (a drink derived from the distillation of the agave tree) to pre-Hispanic civilizations. The tree was not only used in daily-life organization, such as for building, etc., but the beverage was also used for celebrations and social acts, a fact which was regarded by the colonizers as an act of an inferior moral value. The indigenous peoples, when mixing it with other roots and drinking it in large quantities, lost their reasoning capacity (gente sin razón

* I am indebted to the Spanish Ministry of Education, Culture and Sports (PGC2018094659-B-C21); FEDER; and the Basque Government (Dpto. de Educación, Universidades e Investigación / Hezkuntza, Unibertsitate eta Ikertuntza Saila, IT 1026-16) for funding the research carried out for this essay. 
as they were considered by the colonizers), and engaged in violent acts, or worse, in carnal ones (20). For the following centuries, drinking pulque was considered an inferior act in the hierarchical organization of the colonies and remained as such for centuries. According to Gaytán, it was in this period that pulque and its derivations were soon equated to indigeneity (25). However, according to Chantal Martineau, for the indigenous peoples, drinking pulque was considered to be a sacred act available only to a few chosen individuals, and "[o]nly high priests and tribal chiefs were permitted to partake of the beery liquid, which they believed allowed them to communicate with the gods. The general population was mostly banned from drinking pulque; exceptions were made for the elderly or those who had taken ill and were in need of pulque's mysterious healing powers" (56). The colonists, for their part, drank wine and ate food brought over from Spain, in an attempt to mark a clear hierarchical gap between the two communities. By the seventeenth century, however, the drink became more popular among the mestizo and mulato populations, as well as the lower-class Spanish. Pulquerias were established and selling pulque became a regulated act, which brought an illegal commerce too (Gaytán 25). As Martineau explains, by the twentieth century, "the drink had become synonymous with the lower classes - and with a swarm of health risks. Unsanitary conditions in production facilities plus poor handling, storage, and shipment of pulque were rumoured to be the cause of widespread poisoning" (59). This was until it became, once again, a popular, even hipster drink, both in Mexico and outside its borders, directly linked to "lo mexicano," a widely recognized national symbol.

\section{TEQUILA AND “LO MEXICANO”/“LO CHICANO”}

\section{In The Philosophy of Food, David M. Kaplan affirms that:}

Food and drink figure into our everyday lives in countless ways. A diet expresses ethnic, religious, and class identification; it prescribes gender roles; it is embodied in rituals and manners; and it relates directly to our aspirations to perfect ourselves. Food and drink tap our pleasures and anxieties, memories and desires, and pride in or alienation from our heritage. This connection between diet and identity raises a number of philosophical questions. Nothing we eat (short of poison) determines an identity. And yet dietary preferences are indeed a part of who I am individually and who we are collectively. Sometimes the role of food is trivial (e.g., one's idiosyncratic tastes and food memories); sometimes significant (e.g., sugar and the Atlantic slave trade, or Ireland and the potato in the 1840s). Either way, food is a marker of identity. (18)

Regardless of risking being essentialist and stereotypical, it is today undeniable that definitions of "lo mexicano," in terms of drinking habits, are related to tequila. As mentioned previously, however, this direct equation of Mexican identity and the drink was not always a positive one, and it was not until the mid-twentieth century that the drink acquired international recognition, a social status, and the labelling of "the national Mexican drink." According to Martineau, a key moment 
of this turn to national and international status came in the 1940s and 1950s, when Mexican cinema introduced tequila in the plots of movies, which dealt with charros and cowboys and, thus, in the imaginary daily lives of the protagonists of popular movies (298). Indeed, Gaytán affirms that, “Tequila’s ubiquity in Mexican cinema heightened its ties to Mexican identity both within and outside of the nation. On the legislative front, industrialists began initiating steps to conserve tequila's association as an exclusively Mexican drink" (10). The relevance that tequila acquired both within and outside Mexico, transcended the economy that surrounds the production and consumption of tequila, but, as highlighted by Gaytán, reached the popular notion of the drink as a marker of a collective identity, which would define "lo mexicano." Similarly, this identity has permeated both the national and international assumptions on the collective, imaginary identity of Mexicans, and tequila has become an uncontested popular emblem with which Mexicans relate.

In her work ;Tequila! Distilling the Spirit of Mexico, Gaytán expands deeply on this relationship between tequila and "lo mexicano" and proposes a direct link between the essentialist universal understanding of Mexico with the Mexican Revolution, and with Pancho Villa in particular. For her, this link between the revolutionary, the revolution, Mexico and the drink has presented "tequila as a populist symbol of lo mexicano (Mexicanness). The rise of Villa as a tequila-drinking national icon is the result of a factious interplay of clashing political ideologies, racial stereotypes, notions of masculinity, and media representations" (45). In this sense, the post-Revolution rise of the notion of mexicanidadllo mexicano encouraged the idea of a mestizo identity and raised revolutionary masculine symbols, such as that of Villa. According to Gaytán, in a country where the majority of the foundational identitarian symbols of the country were related to feminine figures, such as the Virgen de Guadalupe,

after the revolution this phenomenon shifted, and male figures became more visible in order to accommodate the patriarchal impulses of modernization. The momentum of modernity operated within the scope of a masculine agenda, or "national fantasy" in which male icons mapped the country's "glorious" past onto its "coherent" present. Specifically, the charro became a prototype used for marketing "Mexican culture for public consumption both inside and outside of Mexico." ... Drinking and fighting were expressly prohibited because carrying a real gun was part of the charro regalia. ... Although the charro was one example of a particular version of Mexican manliness and a symbol of "good" citizenship that was promoted locally and internationally, another icon also started to emerge during this period —one that stood in opposition to the state's representation of respectable Mexican manhood: the legendary rebel General Francisco "Pancho" Villa. (51)

As expressed previously, the masculine symbol of Pancho Villa has permeated better in the international imagination of the Mexican identity, and together with it the idea of a certain type of masculinity, which, as observed earlier, directly related to bravery, honor and drinking tequila. 
Drinking is considered, in most societies, a social act. In fact, one could talk of the existence of a "drinking culture" (Wilson), which is performed not only individually, but mostly in a group environment. For Thomas M. Wilson, in fact, drinking is (as corridos are), "the stuff of everyday life, quotidian culture which at the end of the day may be as important to the lifeblood of the nation as are its origin myths, heroes and grand narratives. Drinking cultures are aspects of other cultures, part and parcel of wider webs of significance, broader fields of affiliation, identification and action. Drinking is itself a practice of differentiation, an example of cultural praxis" (12). In this process of collective communion, the kind of alcohol one drinks is undoubtedly also a product of cultural differentiation, and of national or even regional identification and differentiation. Tequila, including each of its types and derivations, is considered to be a symbol of Mexican identity, both outside and inside its national and cultural borders.

Similarly, the social act of drinking is directly assimilated as an act of individual identification within a group. When this social act is performed, traditionally in public spaces, such as bars, pubs or cantinas, there occurs a "natural" (socially constructed) gender separation during the performance of such a social act. Drinking in public has traditionally been considered an act related to the public sphere of life and is, thus, a male act. Many scholars have related drinking to a certain public reinforcement of masculinity, or a particular hegemonic masculinity, recurrent both in the social, cultural praxis of societies and in its popular cultural representations. Such is the case of Mexico and the United States, and we could translate this same notion to other Western countries. Thus,

American culture has linked "being a man" (dominant masculinities) with alcohol use. Toughness means being able to "hold your liquor" or drink vast quantities (binge drinking) without serious social consequences. Cultural themes of being able to fight, if challenged, play out daily in the media and in bars as a man seeks to maintain his sense of his masculinity. Alcohol use enables non-relational sexuality-being able "to get a girl" for sex, homosociality, and "having fun" where drinking with the boys is very different from drinking with the girls. (West 373)

Hence, drinking is a social, public, male act and it has been represented as such in popular culture. In the particular case of Mexican tequila, both in real life and in its several popular representations, men are protagonists and women, as in the case of the comedias rancheras, "on occasion worked as servers, sold snacks, or sang songs" in the cantinas (Gaytán 69). There, "tequila is almost always the drink of choice for male characters" (Gaytán 69).

As a representative of the popular manifestation of "las cosas del pueblo," corridos, the popular sung narrative form originating in the mid-nineteenth century, are valid examples to observe the relevance of tequila for the construction of a Mexican/Chicano national identity, and in particular, a male one. Corridos, as observed by Américo Paredes (1958) among others, are typically songs that account 
for the bravery and honor of male protagonists, who are, in many cases, involved in acts of defence of a just cause, such as fighting the oppressive authorities, and so on. For this purpose, and starting from the idea that alcohol has traditionally been linked to the enhancement of a public performance of masculinity, I find it interesting to observe the way drinking, or drinking tequila in particular, as a Mexican/Chicano national symbol is represented and acquires meaning in the popular (male) form of the corrido.

\section{CORRIDOS, LOS TIGRES DEL NORTE AND TEQUILA}

Corridos have traditionally served to "pass stories on," to transmit popular knowledge, to account for daily life issues, to connect people across geographical boundaries and generations and, in sum, to maintain popular culture and traditions. The case of Los Tigres del Norte is an exceptional one of national and international success and recognition: their cross-cultural essence (all their members were born in Mexico, but the band was formed in San José, California) provides them with the authority to speak for people on both sides of the US-Mexico border. As such, they have become, for many, the voice of immigrants who want to reach El Norte, of citizens on both sides of the border, and as such are "the voice of the people." Mariana Rodríguez, in her comparative work on the political relevance of Los Tigres del Norte and El Vez, says about the band:Los Tigres del Norte record and celebrate the Mexican migrant experience of immigration in their lyrics. They sing about the discrimination faced by Mexicans while emphasizing the importance of Mexican immigrants in the US, labor market and their contribution both to the USA and to the construction of El México del norte/el otro México. They also continue, explicitly or implicitly, the corrido tradition's main function as a genre that narrates Mexican immigrant community life and aspirations. But Los Tigres del Norte also depart from traditional border corrido, those narrating the adventures of a brave man and his struggles with the Texas Rangers and other agents of the US state, by using female characters in their songs.

These words summarize the political and cultural relevance of Los Tigres del Norte and their indubitable role in bringing the stories of those who live an invisible existence (immigrants, undocumented people, laborers, and so on) to the public scene. In this light, numerous works from academics, journalists as well as cultural and music critics have taken note of the band's activism. In this essay, however, it is not my intention to disregard their relevance on these matters, but rather to observe the way the band include in their lyrics elements of what is considered "Mexicano/Chicano," such as drinking (tequila), and the way this promotes a certain understanding of Mexican/Chicano masculinity.

Scholars such as Samuel Ramos and Octavio Paz equate Mexican/Chicano masculinity to the macho figure, or to his praxis, machismo. Chicano sociologist Alfredo Mirandé labels this definition of machismo as the "compensatory model, ... ultimately motivated by feelings of powerlessness that can be traced to the Spanish 
conquest of Mexico.... The powerless, colonized man thus compensates for feelings of inadequacy and impotence by assuming an overly masculine and aggressive stance relative to women and the rest of the world" (67). Mirandé, on his part, defends the historical and sociocultural evolution of the term, and defines machismo, or being a macho, as a positive model, "the ethic model," where the macho

is not cold and insensitive, but warm and emotional. Rather than being driven by feelings of inferiority or a desire to control others, his behavior is motivated by the desire to uphold his own honor and the honor and integrity of the group. The essential components of machismo are not violence, aggressiveness, or virility, but honor, respect, dignity, and bravery. A real macho is a man who has earned the respect of his family and community. Within the family, the wishes of the man as titular head of the household are more likely to be heeded because he is honored and respected than because he is feared. (68)

In this context, this essay originates from the following three premises: 1 . The relevance of Los Tigres del Norte to the expression of "las cosas del pueblo;" 2. The symbolization of tequila as "una cosa del pueblo Mexicano/Chicano;" and, 3. The importance of alcohol for the performance of masculinity. Thus, it is my intention in the following paragraphs to observe the way (drinking) tequila, or even drinking in general, is portrayed in the lyrics of Los Tigres del Norte with the aim of drawing conclusions about the way this is related to a particular understanding of Mexican/ Chicano masculinity. It is interesting, at this point, to include several lines of two corridos by Los Tigres del Norte, lines which support the two conceptual axe of the three promises: on the one hand, the relevance of corrido, and on the other, their understanding of masculinity.

The first stanza of "Jefe de Jefes," from the album of the same name (2008), is an example of the relevance of the corrido as an expression of "people's stuff:" "A mí me gustan los corridos / por que son los hechos reales de nuestro pueblo / Sí a mi también me gustan / por que en ellos se canta la pura verdad" (I like corridos because they account for our people's real facts). These words account not only for that fact, but also for the idea that what is said in corridos is "la pura verdad," the truth, and in many cases, even the historical truth. Especially relevant to this work is the following corrido, where Los Tigres del Norte clearly define their ideological standpoint in terms of the gender relationship and their conception of traditional machismo. ${ }^{1}$

"El macho y el hombre"

Yo iba adorar la grandeza de un hombre

por todos los hijos que dejó regado

$y$ he visto inocentes llorar su desgracia

vagar por el mundo triste y olvidados.

1 A summary of the corridos will be offered hereafter. 
Yo he visto mujeres llorar su abandono perderse en el vicio por un mal cariño morir poco a poco cual dijo el poeta recordando un macho y arrastrando un nińo.

El macho y el hombre son polos opuestos, uno es la vergüenza y otro es el deber macho es el que deja hijos por doquiera

hombre el que los cría, los educa, los guía y les da de comer.

He visto a los machos matar por la espalda y llenar de lodo a una buena mujer presumir su hombría cuando andan borracho

pero enfrente a un hombre no saben que hacer. ${ }^{2}$

The lyrics of "El macho y el hombre," from the year 1986, are coincidental with Mirandé's theories on machismo, both in chronological and conceptual terms. El macho, "la vergüenza" (shame), a man who "mata por la espalda" (kills from behind"), "presume de su hombría cuando anda borracho" (boasts about his manhood when he is drunk), "deja hijos por doquiera" (leaves children everywhere) responds to the traditional notion of Mexican/Chicano masculinity, addressed in what Mirandé denominates as "the compensatory model," or what Scott Baugh defines as "the power a macho male possesses within the family structure [that] represents his primary outlet of self-expression" (4). Interestingly enough, in an attempt to bring the corrido to the field of study of this article, the macho is a man who drinks, gets drunk and, implicitly in the text, is violent and aggressive because of his use and abuse of alcohol. El hombre (the man), for Los Tigres del Norte, is a man who represents "el deber" (duty), "el hombre el que los cría, los educa, los guía y les da de comer" (los hijos) (raises, educates, guides and feeds them). This description of "el hombre" (the man) similarly corresponds to Mirandé's ethic model: a man who is caring, affectionate and responsible towards his and his family's life.

The observation of the many corridos that Los Tigres del Norte have recorded in their long and prolific career leads me to a first general conclusion. Alcohol, tequila in particular, is not among the most recurrent themes of the lyrics of the band. However, within the songs that address the act/fact of drinking in general, and drinking tequila in particular, I will, in the following lines, group them into what I label (mimicking Mirandé's and Mary Douglas's terms) songs which portray compensatory drinking and those which portray what I will label as celebratory drinking.

2 The corrido makes a clear differentiation between the macho and the man as they represent opposing masculine figures. The former symbolizes shame: he has several children and does not care about them and boasts about his manhood when he is drunk. The latter symbolizes duty, educates and feeds his children. 


\section{LOS TIGRES DEL NORTE'S CORRIDOS AND COMPENSATORY DRINKING}

Most of the corridos of Los Tigres del Norte that include drinking in general, or drinking tequila in particular, can be included under the group that portray "compensatory drinking." All of these, as a general rule, have a man as their main protagonist, who, in most of the cases, is presented as an abandoned man, crying for the loss of a woman. Love, or unrequited love to be more specific, is at the center of this group of corridos, whose tone and style is repeatedly similar in all of them. Thus, in "Amorcito Norteño" (1976), the voice sings:
Amorcito norteño
Aquí está tu dueño
Que te viene a cantar
Yo también me desvelo
Porque sé que te quiero
Sin poderte olvidar.
Si me miras borracho
Si me miras tomando
Por tu amor ha de ser
Porque tú no comprendes
Cuando lloran los hombres
Por alguna mujer.

Cuando alguna mujer

Se nos mete en el alma

Sólo queda el beber

Y la vida se acaba. ${ }^{3}$

Or, in “La mesa del rincón,"(2011) (the corner table), a man cries equally for a woman and does not want to be seen: "Ahí en la mesa del rincón,/ Les pido por favor,/ Me lleven la botella./ Quiero estar solo, / Ahí con mi dolor, / No quiero que alguien diga / Que le he llorado a ella."’ Also, in "Cariño dónde andarás" (1993), an abandoned man wonders where "his lost woman" is, who she is with and resorts to drinking as the only way out. "Cariño donde andarás con quien te andarás paseando / no me calienta ni el sol por eso vivo en el trago / sólo la muerte es ausencia, tú volverás a mi lado." Or "El artista" (2002), which states that "desaparece las penas con tequila y con canciones" (sadness disappears with tequila and songs), tequila is used to compensate for sadness. "Qué voy a hacer sin tî" (2009) similarly portrays the sadness of a lonely man, who, this time, blames the woman for his use of alcohol.

3 A man is crying and drinking for the love of a woman, who left him. He affirms that, in such a situation, drinking is all that is left.

${ }^{4}$ A man is crying and drinking alone and does not want anyone to see him cry for a woman.

5 A man wonders where "his woman" is, who she is walking with. Only drinking helps him. 
Que voy hacer sin ti

hoy tu ausencia me lastima

no era cliente de cantinas

pero ya lo soy por ti.

Esta copa va por ti,

las que siguen van por ti,

si me enfermo, si me muero,

si me lleva la tristeza,

todo ese montón de culpas

te las van a echar a ti. ${ }^{6}$

This same situation is portrayed in "Se me acabó el Tequila" (2014), this time with a direct reference to tequila, instead of a generic, symbolic reference to alcohol or cantinas as a whole. In these corridos, tequila is portrayed as having healing properties for men who feel abandoned and betrayed by women.

Que venga el cantinero a servir

Se me acabó el tequila

Aquí en la cantina voy a estar

Bebiéndome mis penas.

Si antes era un triunfador

Hoy vivo derrotado

De cuerpo y alma me entregué

Y solo me han dejado.

Estoy encadenado a mi dolor

Y yo no sé hasta cuando

A veces me reclama el corazón

De amar sin nada a cambio.

Voy a tratar de cauterizar

La herida que yo traigo

Con sal, limón y tragos de tequila

Que me está faltando.

Se me acabó el tequila que vengan a servirme por favor

Hasta que yo la olvide o deje de latir mi corazón

Se me acabó el tequila y a nadie yo le pido compasión

No voy hacer el último borracho

Que sufre, muere y llore por amor.

Que venga el cantinero a servir

Se me acabó el tequila

${ }^{6}$ A man says he was never a cantina customer. He blames a woman for having left him and having "pushed him" to the cantina, making her responsible for his fate (death, diseases, etc). 
Que ponga a los norteños a cantar

Que sea las golondrinas.

Adonde ira la que se fue

Y que juro quererme

Maldigo en que la encontré

Y que me enamoré nomas para perderte. ${ }^{7}$

The corrido "Te odio y te quiero" (1990) similarly makes reference to forgetting and drinking alcohol (wine, in this particular case) and says: "No quiero nombrarte y busco en las copas / El vino y olvido que nunca será" (I don't want to name you and I find in drinking and wine the oblivion that will never be). Likewise, in "Tu recuerdo y yo" (2008), the protagonist sings: "Estoy en el rincón de una cantina oyendo una canción que yo pedí me están sirviendo ahorita mi tequila ya va mi pensamiento, rumbo a tí" (I am sitting in the corner of the cantina, listening to a song I asked for. As my tequila is being served, my thoughts are about you). Finally, in "Un mar de vino" (1995), the man defends himself from his ex-lover's friends, who accuse him of having to forget the woman's love through an indiscriminate use of alcohol (wine in this particular case).

Un mar de vino

yo no lo necesito

con unas copas me basto para entender

que los amores no son buenos a la puerta

tampoco es bueno rogarle a una mujer

aunque no niego que todas son hermosas

pero hay ingratas que no saben amar

por que un espejo refleja su belleza

luego el desprecio su contra vanidad

que yo te quiero dijiste a tus amigas

que no te olvido ni teniendo un mar de vino

por que me vieron tomado en la cantina

grite tu nombre cuando estaba bien bebido

que yo te quiero dijiste a tus amigas

que cuando quieras me tienes en tus manos

eso es mentira por que aunque no lo creas

si yo te quise ya se me esta olvidando

un mar de vino

yo no lo necesito

con unas copas me basto para sanar

7 A man is drinking and crying in a cantina. He was once a successful man, but "his woman" has left him and he is a loser now. He tries to forget about his sad situation by drinking tequila. 
aquella espina que dejaste aquí en mi alma

por tu carińo no volveré a tomar ${ }^{8}$

$\cdots$

All in all, the compilation of corridos that portray men drowning their grief in alcohol, wine and tequila particularly, lead to two general conclusions about their message regarding masculinity and the use of alcohol for men. First, we can clearly conclude that the protagonists of all these corridos are men and the songs are sung by men. This apparently insignificant fact is symbolically quite relevant. On the one hand, it connects all men who are experiencing the same situation, have experienced it, or will in the future. On the other hand, this fact makes the stories of the corrido partly universal and, thus, they instantly become shared and received as "las cosas del pueblo." Second, the characterization of the male protagonist of these corridos is astonishingly similar in all of the songs: they are suffering, crying, sensitive men, who show their feelings openly and share them with those participating in the performative communicative act that these corridos propose. Both the singers, the protagonists of the lyrics and those receiving and eventually reproducing them are men (and women), who have (or have not) experienced the same situation and, thus, understand that crying, grieving and showing emotions publicly are all part of what being a man is. This masculine model responds to the one defined by Mirandé as representing the "ethic model" of manhood and masculinity. As for the portrayal of women in these corridos, we can conclude that, on the one hand, women are portrayed as agentic individuals who have a voice and, in this particular case, women who have chosen to abandon these men. As Rodríguez affirms: "These female characters are often as powerful and brave as their male counterparts, thus marking the group's rejection of the subordinate place of women in Mexican immigrant and Chicano/a patriarchal cultures" (3). On the other hand, this same act, the act of speaking up, can be understood as an act of betrayal on their part towards the male protagonists of the corridos. This is, in a way, a contradictory portrayal of the women, who are represented as free, voiced women, but they are also represented as unfaithful, to-blame women.

With respect to the act of drinking alcohol, two conclusions can be reached as well. On the one hand, drinking is in many cases represented as an abstract concept, with its consequences, such as being drunk, borracho, being emphasized. On the other hand, we also see the protagonists just drinking, tomando, or with a glass in their hands, or with a botella, a bottle. The second conclusion relates to the idea that this act of drinking, considered "compensatory drinking," is always an individual act. As expressed by Douglas, "Just because alcohol in this setting is the gate of access to all that is most desired, a person suffering social rejection would understandably turn to compensatory drinking, to possess at least the symbol of what he does not have" (8-9). Feeling sad, the protagonists resort to drinking to compensate for the

${ }^{8}$ A man defends himself and accuses the woman who left him of telling her friends he is in love with her and crying for his loss. He says that he does not need to drink a lot, but just needs some wine to forget about her. 
loss of the loved person and this is performed solitarily, even if it is always done in a cantina, a bar or a public drinking space. Finally, we could affirm that, in this type of corrido, tequila is not necessarily the preferred drink, and, thus, tequila is not conceived as the only alcoholic drink that one could use for this purpose. In this light, the opening premise that equated (drinking) tequila with Mexican/Chicano masculinity does not prove to be true after the observation of these corridos.

\section{LOS TIGRES DEL NORTE'S CORRIDOS AND CELEBRATORY DRINKING}

The second group of corridos, which deal with the act of drinking alcohol in general, or tequila in particular, can be labelled under the name "celebratory drinking." A notable example is the corrido "Ando amanecido" (1999):

Si las despierto chiquillas bonitas

Si se molestan ustedes perdonen

Allí me dispensan que yo ande contento

Traigo al conjunto cantando canciones

El acordeón que bonito retumba

Allí me dispensan muchachas el ruido

Allí me reclaman mañana o pasado

Ahorita no porque ando amanecido

Por Dios santito que México es chulo

No hay otra tierra como el suelo azteca

Por eso es que ando arrastrando al conjunto

Con mis amigos con vino y cerveza

Hasta que el cuerpo y la bolsa me aguante

Voy a gozarla mientras que yo pueda

Ahorita somos mañana quien sabe

Ya lo sabemos qué mundo allí te quedas

No tengo yo compromisos de amores

Yo soy de todas y a todas las quiero

Soy como el pájaro de rama en rama

Y cuando quiero levanto mi vuelo

Por Dios santito que México es chulo

No hay otra tierra como el suelo azteca

Por eso es que ando arrastrando al conjunto

Con mis amigos con vino y cerveza ${ }^{9}$

...

9 A man celebrates life, friendship and the beauty of Mexico by drinking wine and beer with his friends. He boasts about the fact that he likes all women and can have them all. 
There is also "El cheque" (1972), which says: "Despues de cambiar el cheque, me fui para una cantina para aventarme unos tragos / estaban unos mariachis, sin sombrero y con huaraches / cantando el Juan Charrasqueado."10 "Al estilo mejicano" (2006) sings to the beauty of women all over Mexico and celebrates Mexican identity by praising the different alcoholic drinks that define each of the Mexican regions. The corrido says: "Lo mismo tomo una cerveza allá en el norte / Que me echo un Pulque en las tierras del bajío. / Voy a San Luís a saborear de su Colonche / O un buen Tequila si ando en suelo Tapatío." "Le felicito amigo" (2002) celebrates the gifts of a man, who says: "Me gusta la parranda, la vida bohemia/me gusta el buen vino y puedo amanecer tomando / la copa con buenos amigos" (I like partying, bohemian life, and good wine. I can stay up all night drinking with good friends). In a similar vein, "Los malportados" (2007) praises the deeds of a group of friends, who like parranda (fiesta, partying), and are portrayed as wholly indifferent to what the rest of society thinks of them.

Los mal portados nos dicen todos, porque gozamos al vivir a nuestro modo nos entregamos a los placeres, el canto el baile la parranda y las mujeres Los mal portados así nos llaman y nuestra fiesta es siete días a la semana porque el futuro siempre es incierto por eso amigos hay que vivir el momento. ${ }^{11}$

In general terms, the corridos, which fall in the "celebratory drinking" group and are less abundant than those labelled as belonging to the group of "compensatory drinking," are also present in the Los Tigres del Norte's song corpus. After browsing some of their lyrics and their symbolic representation of the act of drinking, we can come to two conclusions. Contrary to the previous group, most of these corridos portray drinking as a collective, social act with friends, families and/or colleagues. The idea of parranda (partying, fiesta), which implicitly includes drinking in/with a group, is present in most of them, and drinking is performed as a celebratory act. In this sense, the idea of celebration, making the most of life and enjoying it, is directly related to drinking and its ensuing parranda. Douglas would label this as "constructive drinking," and as a whole it is represented as a collective ceremonial act, an act which unites people (men, mostly) and creates a sense of collectivization and belonging. As expressed by Douglas, in this case, "drinks also act as markers of personal identity and of boundaries of inclusion and exclusion" (8). In this sense,

10 After cashing a check, (a man) goes to the cantina to celebrate it with some drinks. Some mariachis are singing.

11 This is a carpe diem corrido, where a group of men explain that they like partying, drinking and women. For that reason, they are called "the bad-behaved." 
and as observed, some of the corridos, which celebrate drinking, do connect with praising Mexican identity, as is the case of "El cheque" and "Al estilo mejicano."

It is, however, interesting to note that, in some of these corridos, their protagonists are representative of what Mirandé calls the macho figure, a persona who follows the "compensatory model," where a man boasts about his freedom and his relaxed relationship with women, as in the case of "La hija la mama" (2014).

\author{
Sentado en un bar \\ tomándome un trago \\ de pronto que veo \\ una alucinación \\ Había en la puerta \\ dos hembras muy lindas \\ la hija, la mama \\ ay válgame Dios \\ Que se para mi \\ debo estar tomado \\ señor cantinero \\ ya no me dé más \\ Porque ya no puedo \\ saber cuál de todas \\ la hija o la mama \\ me quiero llevar. ${ }^{12}$
}

The idea of connecting the act of drinking with engaging in a relationship with women, and not only that, as in the case of seeing oneself able to "choose" between the mother and the daughter, represents a kind of manhood which, according to Mirandé and even Los Tigres del Norte themselves, as we saw in the corrido "El hombre y el macho," shows no positive characteristics.

\title{
CONCLUDING REMARKS
}

In summary, we can infer that the starting premise of this article, that is to observe the way Los Tigres del Norte's corridos represent the "everyday-stuff" status of alcohol, and in particular of tequila, as a vehicle for the construction of a Mexican/ Chicano masculine identity, results in the following general conclusions. On the one hand, drinking is present in many of the corridos of the band. However, there is no proof of the prominence of tequila above other drinks. The idea of drinking as an abstract act, portrayed directly as a means of getting drunk (most of the times,

${ }^{12}$ A man is sitting in a bar, drinking, when two women come in: a mother and her daughter. He "wants them" both. 
alone), is vital in many of the songs of the band. When there is direct reference to the kind of drinks that are used for the act of drinking, tequila, wine and even beer are named, but there is no prominence of one over the other. In many of the cases, the idea of partying, or what we label "celebratory drinking," is also present in many of the band's corridos, and once again there is no prominence of one drink over the other, but it is also true that when drinking is used to celebrate, this is always connected to a collective, communal act.

The most relevant conclusion of this observation, however, is related to the way drinking connects directly to a particular performance and representation of masculinity. In most of the cases, all corridos by Los Tigres del Norte are not only performed by men, but they also show men as protagonists. We could even infer that, implicitly, many times one could think that they are addressed to men and create an empathic connection with the male audience. In the case of the observed corridos and the way they portray a representation of men and masculinity, there is a clear distinction between those songs that portray "compensatory drinking" and, on the other hand, that allude to "celebratory drinking." The former show sad, sensitive men, men who are crying for the loss of love or of their beloved women. In a way, these corridos portray a positive representation of men, at least in the public performance of their grief and in the wholehearted statement of their feelings. However, it is also true that in many of these corridos, the women are not portrayed in such a positive light and, in fact, they are blamed as betrayers. Finally, those songs which portray drinking as a celebratory act are in many cases related to men, whose attitude is more aggressive or related to the macho figure, the boasting, proud and even aggressive man, whose relationship to women is more traditional or "relaxed."

All in all, drinking is undoubtedly part of the everyday life, as well as individual and social acts of most social communities, and the case of the Mexican/ Chicano is no different. As such, and in the "sung newspapers" that corridos represent, drinking is present in these songs, songs which connect to their audience by sharing the praxis and the results of the act of drinking because, "los corridos son las cosas del pueblo" and "drinking is the stuff of everyday life."

REVIEWS SENT TO AUTHOR: 21-5-2020; REVISED PAPER ACCEPTED FOR PUBLICATION: $14-8-2020$ 


\section{WORKS CITED}

Baugh, Scott. "Changing of the Guard; Pinche Pintas and "Family"/Familia in Contemporary Chicano Film." Journal of Film and Video 55/2/3 (2003): 3-20.

Douglas, Mary. Constructive Drinking. Perspectives on Drink from Anthropology. Routledge, 2003 [1987].

Gaytán, Marie Sarita. ¡Tequila! Distilling the Spirit of Mexico. Standford UP, 2014.

Kaplan, David M. The Philosophy of Food. U of California P, 2012.

Los Tigres del Norte. "Al estilo mejicano." Historias que contar, Fonovisa, 2006.

Los Tigres del Norte. “Amorcito Norteño.” Pueblo Querido, Fama, 1976.

Los Tigres del Norte. “Ando amanecido.” Herencia de familia, Fonovisa, Universal, 1999.

Los Tigres del Norte. "Cariño donde andarás.” La garra de..., Fonovisa, 1993.

Los Tigres del Norte. "El artista." La reina del Sur, Fonovisa, 2002.

Los Tigres del Norte. “El cheque.” El cheque, 1972.

Los Tigres del Norte. "El macho y el hombre." Gracias... America!... Sin Fronteras, Profono Internacional, 1986.

Los Tigres del Norte. "Jefe de Jefes." Tierra de Jefes, Fonovisa, 2008.

Los Tigres del Norte. "La hija y la mamá.” Realidades, Fonovisa, 2014

Los Tigres del Norte. "La mesa del rincón.” Los dos plebes, Fonovisa, 1994.

Los Tigres del Norte. "Le felicito amigo." La reina del Sur, Fonovisa, 2002.

Los Tigres del Norte. "Los malportados.” Detalles y emociones, Fonovisa, 2007.

Los Tigres del Norte. "Qué voy a hacer sin ti." La Granja, Vale Music, 2009.

Los Tigres del Norte. "Se me acabó el tequila." Realidades, Fonovisa, 2014.

Los Tigres del Norte. “Te odio y te quiero.” Los adoloridos, Fonovisa, 1990.

Los Tigres del Norte. “Tu recuerdo y yo.” Raíces, Fonovisa, 2008.

Los Tigres del Norte. “Un mar de vino.” El ejemplo, Fonovisa, 1995.

Martineau, Chantal. How the Gringos Stole Tequila. Trinity UP, 2019.

Mirandé, Alfredo. "Qué gacho es ser macho: It's a Drag to be a Macho Man.” Aztlán: A Journal of Chicano Studies 17/2 (1986): 63-89.

Paredes, Américo. With His Pistol in His Hand. A Border Ballad and Its Hero. U of Texas P, 1958.

PAz, Octavio. El Laberinto de la Soledad. Fondo de Cultura Económica, 1950.

Ramos, Samuel. El perfil del hombre y la cultura en México, ed, Espasa-Calpe, México, 1985.

Rodríguez, Mariana. "We Are America!” Cultural Politics and Chicano Movement Legacies in the Work of Los Tigres del Norte and El Vez. MA Thesis, Institute for International Studies, U of Technology Sydney, 2007.

West, Lois A. “Negotiating Masculinities in American Drinking Subcultures.” The Journal of Men's Studies 9/3 (2001): 371-92.

WiLson, Thomas M. Drinking Cultures. Alcohol and Identity Formation. Berg Publishers, 2005. 
